\title{
Grei bok med marginal nytte
}

\author{
Anmeldt av Kim Larsen
}

BOKEN SKAL som tittelen indikerer integrere suicidologisk forskning og selvmordsforebyggende praksis. Den er delt inn i fire deler. Del én handler om hvordan denne integrasjonen kan oppnås, med et kapittel hver for kvantitativ og kvalitativ forskning. Del to om selvmordsforebyggende intervensioner starter med et kapittel om fenomenologien ved selvmord. Deretter følger to kapitler om hvordan en tenker at selvmordsforebyggende programmer kan ha effekt og problemene med å måle disse effektene. Vi får så et kapittel om selvmord blant yngre og deretter to kapitler om selvmord hos eldre. Del tre handler om sorgen etter selvmord. I bokens siste del oppsummerer Diego De Leo hvordan han ser for seg at suicidologisk forskning og praktisk selvmordsforebygging vil utvikle seg i fremtiden.

Boken retter seg mot både legfolk og fagfolk. De Leo og Poštuvan beskriver i forordet at deres intensjon med boken er å fremme «intuition, imagination and innovation in the research and prevention of suicide and suicidal behaviour». Det sier seg vel litt selv at en så ambisiøs målsetting lett kan bli i overkant for en bok på kun 158 sider fordelt på 12 kapitler. Innenfor en slik ramme vil en kunne gi en innledende orientering om de ulike tema, men heller ikke mer. Dette er en «grei nok» bok, men en bok som også konkurrerer i et marked som er ganske mettet av lignende bøker.

En av foregangsmennene innen psykodynamisk suicidologi, John T. Maltsberger, skrev allerede i 1986 følgende om litteraturtilfanget i suicidologien:

«So massive is the suicide literature that any attempt to master it may stagger not only the mind, but also the back as well ... Forests are destroyed to feed the whirring presses, many new articles and a book or two appears each month» (s. 49).

Det er i retrospekt tankevekkende at Maltsberger på det tidspunkt kun hadde sett begynnelsen til hva som senere skulle komme. Den virkelig store flodbølgen av suicidologisk litteratur inntraff ca. 15 år senere, fra ca. 2000 og fremover, hvor vi fikk handlingsplaner mot selvmord i mange land og samtidig en ekspansjon av suicidologisk forskning. Når en god del av dagens forskning bærer preg av repetisjon og konsolidering av de samme funn, må nødvendigvis

Når en god del av dagens forskning bærer preg av repetisjon og konsolidering av de samme funn, må nødvendigvis litteraturen også bære preg av avtagende grensenytte. 

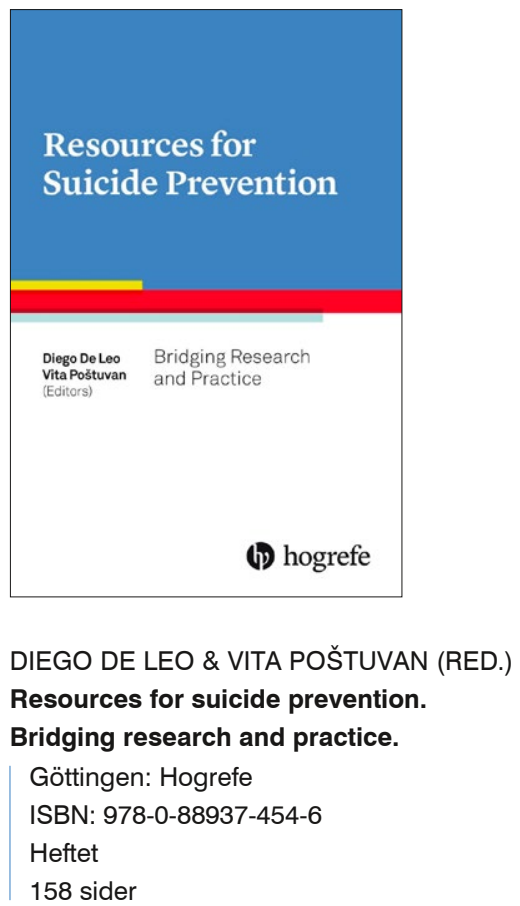

litteraturen også bære preg av avtagende grensenytte. Det er nettopp det som har skjedd, og som den foreliggende bok kan stå som et illustrerende eksempel på. Den må konkurrere med mange ganske like bøker utgitt de seneste 15 årene. Selv synes jeg Keith Hawtons redigerte artikkelsamling Prevention and treatment of suicidal behaviour. From science to practice (2005) gir en bedre og grundigere innføring i mange av de samme tema. Den er imidlertid også betydelig lengre.

Den utviklingen jeg har skissert blir ironisk i lys av at vår akademiske Zeitgeist favoriserer nye publikasjoner, og en angir ofte ti år som en slags holdbarhetsgrense. Dette slår meg å være en slags ahistorisk neofili som ironisk nok kan bidra nettopp til et marked for stadig nye bøker som omhandler det samme. Det er også en holdning som etter mitt skjønn indikerer en naivistisk og nærmest pre-Kuhniansk forestilling om vitenskapen som værende i konstant lineær progresjon.
Resources for suicide prevention. Bridging research and practice er for så vidt hederlig nok i seg selv, men har «uflaks» med sin publikasjonsmessige kontekst av en overflod av lignende litteratur med avtagende grensenytte som resultat. Det er på tide at forfattere og utgivere av suicidologisk litteratur spør seg selv om hvordan en bok vil kunne bidra med noe genuint nytt i suicidologisk teori og forskning eller bidra til forbedret selvmordsforebyggende praksis. Jeg er selvfølgelig glad for en ekspanderende interesse for mitt fagfelt, men det fører dessverre også til en litteraturmengde hvor kvaliteten ikke holder tritt med kvantiteten.

\section{REFERANSELISTE:}

Hawton, K. (red.). (2005). Prevention and treatment of suicidal behaviour. From science to practice. Oxford: Oxford University Press.

Maltsberger, I.T. (1986). Suicide risk. The formulation of clinical judgement. New York: New York University Press. 